\title{
Danylenko, Yu.A.
}

Institute for Scintillation Materials, the NAS of Ukraine,

60, Nauky Ave., Kharkiv, 61072, Ukraine,

+380 57341 0292, j.danilenko@isma.kharkov.ua

\section{CHARACTERISTICS AND CLASSIFICATION OF INNOVATION AND INNOVATION PROCESS}

Introduction. In the past several years, innovations have become a synonym for rapid technological progress. Using cutting-edge technologies and up-to-date models for the innovation process allows corporations to be one step ahead of their competitors.

Problem statement. The research of new ways for the emergence of innovations requires studying the historiography of innovation and tracking changes in the stages of innovative process development. This kind of study stimulates the appearance of modern innovative models that, in turn, can create the conditions for developing the necessary skills to introduce innovations in any context.

Purpose. To examine the existing classification of innovations and models in the innovation process, to systematize and to develop author's own classification of researched objects.

Materials and methods. Logic method, comparative analysis, system approach method, and analogy method have been used for this research. Ukrainian and foreign scholarly research publications on this topic have been used as references.

Results. A historiographic research of the concepts of «innovation» and «innovation process» has been carried out. Special attention is focused on the study of «open innovation». This research has enabled to retrace changes in the concept of «innovation» over time, to classify the existing types of innovations by different features and to distinguish them by categories. Along with that, the dynamics of the innovation process and the models have been scrutinized; the development stages with the respective attributes and disadvantages have been shown.

Conclusions. Nowadays, there are numerous innovation types and they continue to appear constantly, though no unified classification of innovations is in place. The classifications made by Ukrainian and foreign researchers differ by the number of attributes. Moreover, at the level of individual corporation, there is no uniform action plan how to become innovative and to survive in current market economy. The top managers choose independently their innovative way taking into consideration the opportunities and challenges of the market.

Keywords: innovation, innovation process, classification, historiography, development stage, and attribute.

Today, the use of digital technologies, social networks and increasing volume of available information reduces the period for which innovation is created, and significantly cuts innovation life cycle. Search for new directions of innovation requires a careful study of historiography, existing types of innovations, and stages of the development of innovative processes at corporations. Conducting such a study may result in develop-

C DANYLENKO, Yu.A., 2018 ing modern innovative models at corporations, which create the conditions for the development of skills necessary for the emergence of innovations in any context. Creating conditions for the implementation of modern innovative strategies allows corporations to receive innovative ideas, to improve the innovation process, and to make their products and services competitive.

According to [1], innovations are newly created and/or improved competitive technologies, products or services, as well as organizational, tech- 
nical, administrative, commercial or other considerations that significantly improve the structure and quality of production and (or) social sphere.

The term «innovation» is closely associated with such concepts as «novation», «novelty», «invention», and «discovery». The terms «innovation process» and «innovation» are very close but have a different content. The innovation process is the preparation and implementation of innovative changes. It combines several interrelated phases: firstly, the necessity of changes is realized, the goal is determined, then innovation is developed, mastered, diffuses, used, and «dies» [2].

The term «innovation» comes from the Latin «invenire» that means «to find, discover». It appeared in the $13^{\text {th }}$ century and was used in the field of law, but its meaning was entirely different, namely, to reissue a bond by reviewing the contract for a new debtor [3]. Among the few authors who later used this term were Niccolo Machiavelli (1513) and Francis Bacon (1625).

For the first time, the term «innovation» in its modern meaningis encountered in scholarly research of the end of the $19^{\text {th }}$ century, in sociology. In the first innovation theory of Gabriel Tarde [4], innovation is interpreted as a social change in grammar, language, religion, law, constitution, economic regime, industry and in arts. He widely used the term innovation (novation) as a novelty, but without a specific definition of this term. It should be noted that to discuss social changes he used also the terms invention, ingenuity, novelty, creativity, originality, imagination, discovery, and initiative. The author believed that the invention is an imitation of previous inventions. The scholar developed a social theory of change which later was used by Schumpeter.

At the beginning of the $20^{\text {th }}$ century, Joseph Schumpeter, an Austrian economist and sociologist,for the first time used the terms «innovation» and «novation» in economy and associated them with the pace of economic growth. In his first book, The Theory of Capitalist Development (1911), the scholar emphasized the personalization of innovations, i.e. the role of innovator's personality irrespective of clear understanding of ideas motivating him/her to innovate. Also, Schumpeter assumed the innovation process is discrete and random, but, in no way, automatic [2].

In 1912, Schumpeter gave the first classification of technical changes; in 1934, he interpreted technical changes through the concept of creative destruction. He believed it was the essence of capitalism. For him, capitalism manifested itself through destroying outdated, obsolete structures and finding new forms. According to Schumpeter's concept, innovations can be large-scale (radical) that significantly affect certain sectors of the market or small (incremental) [5, 6]. Schumpeter separated the forms in which the technical changes could be implemented in practice: the sale of goods (products) that are new to consumers or of higher quality; the introduction of manufacturing methods that are new for specific industries; the discovery of new markets; the use of new sources of raw materials; the introduction of new forms of competition that lead to structural changes in the areas of their implementation.

J. Smith considered innovations within the concept of cultural change, namely, the features of culture, trade, social and political organization, anthropology and inventions in agriculture. Smith was the first who noted that an invention generated in a certain place could widely diffuse [7, 8].

Bronislaw Malinowski believed that there were many inventors, all inventions had similar forms, but differed in the details of production methods, materials or use. According to him, «the spread of innovation is adaptation, transformation and improvement of the existing products» [9].

In the early 1940s, the first economist dealing with the theory of technological innovation, Rupert Maclaurin, introduced a new meaning to the term «technological innovation» in economic literature, which is associated with developing and commercializing new products in the economy, rather than using technical processes in production. Having analyzed how the process of technological change takes place, Maclaurin divided it into clear and consistent steps, from fundamental 
research to production technology, and then to innovation diffusion [10].

In 1971, Edwin Mansfield also formulated the concept of «innovation» as a technological innovation and a process that leads to its commercialization. Diffusion of innovation begins with the innovator, then the invention is adapted by individuals, groups, corporations, and countries, and then it is replicated. It has a clear sequence, namely: invention - innovation - imitation - diffusion. According to Mansfield [11], the diffusion of technical innovation is influenced by the size of corporation, the role of academic and basic research, and international technology transfer.

According to [7], the concept of innovation diffusion was further developed by Carter and Williams in 1957-1959; the innovative behavior of corporations was studied by Burns, Stalker, and Wilson; more advanced theories of innovation diffusion and simulation in the economy were elaborated by Mansfield, Posner, and Schmookler.

Benoit Godin, in his work «Innovation: The History of the Categories» [12] wrote that the main concepts of innovation were developed in 19601990s, the methodology and models for the analysis of innovation processes were structured, with innovation considered both as process and as object, in particular, innovation as an instrument of change, innovation as a context for change, innovation as the person ability to act and innovation as change in and of itself.

Joe Tidd and John Bessant [13] believed that virtually all economic growth that took place after 1980 was due to innovation. Innovation is a common denominator for successful organizations that have succeeded by creating advantages over their competitors. They have used new knowledge and technology to create or to improve their products and services, as well as to create these products and services. However, innovation is a complex process with a lot of uncertainty. Unfortunately, there is neither simple strategy nor recipe for organizations that should become innovative, and for many, the innovation process is considered to be unmanageable. Today, they face dif- ficulties because they do not develop new skills and strategies to raise the efficiency of their products, services, and business models. Such organizations, as a rule, do not stay in the market for a long period time and usually become uncompetitive. At the same time, organizations that have recognized the importance of innovation and are capable of managing a complex innovation process can withstand competition in the market for decades, as proven by many examples.

Creation, implementation, and diffusion of innovation is the basis of innovation process in the organization that is, as defined by Brian C. Twiss, is transformation of scientific knowledge, scientific ideas, inventions into physical reality (innovation). The sources that cause innovation processes in organizations can be internal (organizational needs resulting from disadvantages and/or weaknesses, the organization's penchant for changes, internal organization research and development, unexpected events within the organization, entrepreneurial capabilities of the owner and/or managers and their dissatisfaction with the current state of the organization, etc.) and external (progress in science and technology, economic and/or demographic changes, changes in social and individual values, international integration processes, purchase of patents, etc.) [14].

The purpose of this research is to study the existing classifications of innovation and models of innovation process, to systematize and to develop our own classifications of objects studied.

Gerhard Mensch divided innovations in the three categories: the basic innovation that possesses previously unmatched properties or properties essentially improved; the improvement innovation that improves and modifies the basic one; and the pseudo-innovation that is innovation made to meet the requirements of product buyers, but involving neither the quality of products nor the technological process changes; they reflect false ingenuity aimed at partially improving noncompetitive technologies [15].

Joe Tidd and John Bessant give a different classification of innovations: the product innovation 
is changes in products or services; the technological innovation is changes in ways of their creation and delivery; the innovation position is changes in the context in which products or services are introduced; the innovation paradigm is changes in the business model organization, including the psychological component [16].

According to the classification of Clayton and Derek van Bever [17], the innovations are divided into:

1. The incremental innovation is improvement of existing products, processes or technologies, that is, raising productivity, expanding functionality, reducing costs, bettering quality, etc.

2 . The radical innovation is innovation that disrupts existing markets offering the world something radically new. The radical innovations are fundamental changes to a product, service or activity, a completely new or substantial transformation of that existed before.

3. The business model innovation. Business model is model of business management that is governing decisions, processes, and risk management applied to generate profits. The business model innovation is unique because it keeps the existing products or services, markets and technology. It directly affects only internal processes inside corporation and is invisible for the end-user. Its additional advantage is that it is very hard to replicate for the competitors.

4. Sustaining or performance-improving innovations replace the old products by new, more advanced versions. Customers willingly buy the new products instead of the old ones.

5. Product, process and service innovations. The innovative process can be realized through decreasing the number of stages in the existing production process, which in turn, reduces its overall cost and, as a result, the cost of the final product. At the same time, the service innovations lead to growing sales, and business models of some corporations are based on ensuring that the service they provide to their customers is one of the most innovative.

Henry Chesbrough, a professor at the University of California Business School (Berkeley), known for his research in the field of innovation, author of famous books Open Innovation, Open Business Models, Open Services Innovation introduced the concept of «open innovation» in «Open Innovation: The New Imperative for Creating and Profiting from Technology». Open innovation is a single whole consisting of two halves.

One is the «outside in» aspect, where external ideas and technologies are brought into the firm's own innovation process. The other aspect is the «inside out» part, where un- and under-utilized ideas and technologies in the firm are allowed to go outside to be incorporated into others' innovation processes. The former is the most commonly recognized feature of open innovation. It gains a critical mass, approaches the turning point, after which the use of the second aspect will become a vital necessity for the players of the modern business field. After all, no matter how intelligent and smart we are, there are a lot of others who are as intelligent and smart as we. And knowingly isolating ourselves from them means putting ourselves in disadvantage or even self-destruction. At the same time, the «inside out» aspect is at an early stage of development as the attitude of the companies to it is still rather cautious, and researchers do not study it a lot (unlike the first one) [18]. Today, steadily high quality will not surprise anyone any longer. In addition, product development cycles get shorter. It is about changing the way of thinking, when the service becomes the foundation of business rather than auxiliary means. Thus, the corporation understands which constraints it has to eliminate, so that product or service becomes a means of creating an unparalleled client experience. After all, this is exactly the essence of true innovation. On the one hand, corporations encourage other players to create something similar on the basis of what they have already developed. On the other hand, this givesthem plenty of opportunities to create a diversified consumer experience.

Henry Chesbrough emphasizes the intellectual property management it is not an easy thing to do, because, in the case of open innovation, it is 
necessary to act not only in your own territory, but also in the territory of others. And here there is a lot of complicated involved questions that can create great difficulties. Sometimes, some corporations leave for themselves, as they say, «key competencies», and transfer R\&D function to outsourcing. Chesbrough stresses the open innovation is a great way to use external knowledge, but he has never considered it to be a substitute for corporation's own R\&Ds [19].

At the basic level, the logic of an open innovation model is based on extensive excessive knowledge that needs to be utilized promptly by the corporationin order to create a new value. Due to financing internal $R \& D$ (research, development, and design works of exploratory, theoretical, and experimental nature) the corporations have created breakthrough innovations and based on them, new products with new properties have been implemented, which has secured high sales and profits. Success in the market generates funds to be invested in $R \& D$ in order to receive and to implement the next generation of new R\&Ds. In the case of unsuccessful innovations, the corporation can lose its position in the markets and terminate its activities as a result. The entire innovation process takes place inside the corporation, with intellectual property rights being a means to protect innovation in the external environment. At the same time, many achievements are not realized in a timely manner, they lose their commercial value, and even gather dust on shelves [20].

In [21], the four main strategies of open innovation are defined:

1) organization of $R \& D$ process through merging into a general fund;

2) development of separate stages of innovation product by different corporations;

3) free sale of broad-based developments that can be used to create various innovative products;

4) a significant reduction in time for decisionmaking in the field of innovation in large firms.

The distinguishing features of new paradigm disclose the formulations of Henry Chesbrough principles of innovation process management, which underlie the open innovation approach as compared with the closed innovation paradigm. These principles are as follows: 1) interaction cooperation with employees outside the corporation will reduce the share of unused ideas; 2) engagement - the external innovative ideas shall be considered at the same level with the internal $\mathrm{R} \& \mathrm{D} ; 3)$ cooperation - the corporation does not have to conduct independent research to profit from the results; 4) modeling - the corporation shall build a perfect business model before entering the market; 5) optimization - the corporation will be a leader if it manages to optimize the use of internal and external ideas in the best way; 6) profitability - the corporation shall intensify activities in the intellectual property market in order to profit from existing intellectual property. For facilitating the development of a business model, the corporations need to acquire intellectual property from other firms.

The disruptive innovation model is Clayton Christensen's theory, which he first introduced in 1997 in his book [22]. This model can be used to describe the impact of new technologies on the operation of firms. The author studied the reasons why world leaders in a particular industry were swiftly losing their dominant positions as new technologies appeared in the market. He believes that everything changes as «disruptive technologies» find their buyer who is ready to accept the new product with its shortcomings and who needs new properties of this product. Having got such a buyer, the new technology begins to evolve, the production grows, and at a certain time, the new technology begins to justify its name «disruptive technology». Disruptive innovations can lift the corporation to a new level of development and can completely destroy business if the company loses its focus. The key to successful «disruptive» innovation is to «undermine» the core of the organization's activities, rather than the periphery. In this case, the «disruptive», as a rule, technological innovation leads to a rethinking of business models, a new cycle of 
Innovation Classification [15-27]

\begin{tabular}{|c|c|c|}
\hline Classification & Innovation type & The essence of innovation \\
\hline \multirow[t]{5}{*}{ Effectiveness } & $\begin{array}{l}\text { Radical / breakthrough / discon- } \\
\text { tinuous / disruptive / revolutionary }\end{array}$ & Extinction of existing markets, radically new products or services \\
\hline & $\begin{array}{l}\text { Transformational / architectural / } \\
\text { manufacturing }\end{array}$ & $\begin{array}{l}\text { Use of new technology implying a principal abandonment of conven- } \\
\text { tional production systems and creation of new relations, customers, } \\
\text { and markets }\end{array}$ \\
\hline & $\begin{array}{l}\text { Sustaining or performance-inno- } \\
\text { vation / improving }\end{array}$ & Replacement of old products with more advanced versions \\
\hline & $\begin{array}{l}\text { Incremental / regular / modifica- } \\
\text { tion }\end{array}$ & $\begin{array}{l}\text { Insignificant changes in the existing range of products, technology, } \\
\text { and systems of management in order to improve them }\end{array}$ \\
\hline & Pseudo-innovations & $\begin{array}{l}\text { Implemented to meet requirements of product customers, neither } \\
\text { significantly improve the product quality, nor modify the process to } \\
\text { improve obsolete technology }\end{array}$ \\
\hline \multirow[t]{12}{*}{$\begin{array}{l}\text { Type of changes } \\
{[28,29]}\end{array}$} & $\begin{array}{l}\text { Business model innovation / para- } \\
\text { digm innovation }\end{array}$ & Creation or reevaluation of business model \\
\hline & Networking innovation & $\begin{array}{l}\text { Cooperation to use ideas proposed by other corporations, including } \\
\text { technology, channels, brands, processes, and proposals }\end{array}$ \\
\hline & Enabling process innovation & Tactics towards involving users into the creation of innovation \\
\hline & Core process innovation & Application of new technology (technological innovation) \\
\hline & Product performance innovation & Quality improvement and reduction in product cost \\
\hline & Product system innovation & Creation of additional products and services to attract customers \\
\hline & Service innovation & $\begin{array}{l}\text { New or essentially improved services, new offerings on warranty ser- } \\
\text { vice and delivery }\end{array}$ \\
\hline & Channel innovation & $\begin{array}{l}\text { Introduction of systems that allow customers to buy goods and ser- } \\
\text { vices in the most convenient way, at minimum costs }\end{array}$ \\
\hline & Brand innovation & Creation of identifiable and unique brands \\
\hline & Customer experience innovation & Use of customer feedback \\
\hline & Structure innovation & Optimal utilization of human resource capacity, expertise, and talents \\
\hline & Profit model innovation & $\begin{array}{l}\text { Identification of real needs of target market and search of capacity to } \\
\text { utilize new opportunities for gaining profit }\end{array}$ \\
\hline \multirow[t]{8}{*}{$\begin{array}{l}\text { New types of in- } \\
\text { novation }\end{array}$} & Eco-innovation & $\begin{array}{l}\text { Obtainment of products and processes that facilitate sustainable de- } \\
\text { velopment }\end{array}$ \\
\hline & Frugal innovation & Development of low-cost strategy aiming at cost prevention \\
\hline & Blue ocean innovation & $\begin{array}{l}\text { Created by expansion or reshaping of the existing boundaries of the } \\
\text { industry }\end{array}$ \\
\hline & Red ocean innovation & $\begin{array}{l}\text { Development of corporation in competitive environment due to the } \\
\text { lack of significant differences in its product from the products of its } \\
\text { competitors }\end{array}$ \\
\hline & Open innovation / crowdsourcing & Corporation gives access to its intellectual pool to others \\
\hline & Experience innovation & Involvement of customers for gaining experience \\
\hline & Niche market innovation & $\begin{array}{l}\text { Proved and completed technology is improved and modified in such } \\
\text { a way as to be able to maintain a new marketing boost }\end{array}$ \\
\hline & Organic innovations & Associated with more efficient use of corporation's own resources \\
\hline
\end{tabular}


development and growth of the company. This is very relevant today, when the rate of appearance of innovation is more important than its effectiveness [23, 24].

As of today, there are many exotic types of innovation, for example:

- The Blue Ocean strategy described in Chan Kim's and René Mauborgne's book on business development under the same title. This is the strategy for creating a new market niche in the already established market and gaining a dominant position in it [25];

- In contrast to the Blue Ocean strategy, the aforementioned authors outline the Red Ocean strategy: the company develops in a significant competitive environment due to the lack of significant differences in its product from the products of its competitors [25];

- The frugal innovations of Tiwari and Herstatt are new or significantly improved products (both goods and services), processes or marketing and organizational aiming at minimizing the use of tangible and financial resources in the complete chain (development, manufacture, diffusion, consumption, and disposal) in order to reduce the production cost or even to exceed certain criteria of already existing quality standards [26];

- The Moore's organic innovations are associated with more rational use of corporation's own resources and introduction of other innovative strategies at the corporation.

Robert Tucker, a world-renowned innovation expert, formulates the five most important principles of attitude towards innovation in the $21^{\text {st }}$ century:

+ to treat innovation as discipline;

+ the innovation shall be binding upon all business units and departments;

+ search for new opportunities shall be systematic;

+ every employee shall be involved in innovation process;

+ the innovation shall be customer-oriented [27]. He distinguishes three types of innovations: the product innovation, the process innovation, and the strategy innovation, and believes that, in the context of high competition and rapid development which are typical for the $21^{\text {st }}$ century, growth can be achieved only through managing the three different aspects of innovation identified. Each of them is very important for the corporation, but paying attention to only one is not enough to secure a growth. The process innovation provides growth of profitability, reduces expenses, increases productivity and salaries of the personnel. The buyer also benefits from innovation of this type, in the form of more qualitative, thoroughly developed products or services. The process innovation remains vital for the growth of corporationin so far, as it is impossible to implement product or strategy innovations without improving the process. The strategy innovation involves reviewing the existing methods for creating a value for customers in order to meet new customer needs, to increase product value, and to shape new markets and new consumer groups for the corporation.

Robert Tucker gives the five important strategic aspects of innovation leadership:

1. Development and implementation of innovation strategy.

2. Allocation of responsibility for innovation.

3. Resource allocation and risk assessment.

4. Creation of a system of indicators to evaluate the innovation.

5. Reward for innovation.

In the opinion of Ukrainian authors [2], the innovation includes:

+ initiation (to formulate the purpose of innovation and the tasks to be performed by the innovation);

+ marketing of innovation (to study demand for a new product or operation, consumer qualities and product characteristics are determined).

+ production (manufacture) of innovation;

+ implementation of innovation;

+ promotion of innovation (to develop measures aiming at the implementation of innovation).

+ assessment of innovation economic efficiency (to systematize and to analyze the results of innovation implementation and the costs of its promotion); 
Sequence of Innovation Process Generations [14, 30-35]

\begin{tabular}{|c|c|c|c|c|}
\hline $\begin{array}{l}\text { Innovation process } \\
\text { generation, years }\end{array}$ & Existing models & Innovation process stage & Process interrelations & Model disadvantages \\
\hline $\begin{array}{l}1^{\text {st }} \text { generation of } \\
\text { innovation pro- } \\
\text { cess }(\mathrm{G} 1[30]) \\
\text { Early } 1950 \mathrm{~s}- \\
\text { mid 1960s }\end{array}$ & $\begin{array}{l}\text { Technology push } \\
\text { model; science } \\
\text { push model; pro- } \\
\text { active model }\end{array}$ & $\begin{array}{l}\text { R\&D and design works } \\
\text { (RDD) Production Mar- } \\
\text { keting }\end{array}$ & $\begin{array}{l}\text { Linear model with focus on } \\
\text { RDD. Market is treated as } \\
\text { innovation consumer }\end{array}$ & $\begin{array}{l}\text { External entities and fac- } \\
\text { tors are not taken into co- } \\
\text { nsideration. Internal cha- } \\
\text { racteristics of process are } \\
\text { not analyzed }\end{array}$ \\
\hline $\begin{array}{l}2^{\text {nd }} \text { generation of } \\
\text { innovation pro- } \\
\text { cess (G2 [30]) } \\
1960 \text { s - early } \\
1970 \text { s }\end{array}$ & $\begin{array}{l}\text { Market Pull Mod- } \\
\text { el/ Need Pull } \\
\text { Model/ Demand- } \\
\text { Pull Model }\end{array}$ & $\begin{array}{l}\text { The processes are similar } \\
\text { to those of the } 1 \text { st gener- } \\
\text { ation, however demand } \\
\text { is a key driving force of } \\
\text { scholarly research }\end{array}$ & $\begin{array}{l}\text { Linear-sequential model with } \\
\text { market needs taken into con- } \\
\text { sideration }\end{array}$ & $\begin{array}{l}\text { Permanent changes; } R \& D \\
\text { plays a passive role, which } \\
\text { results in neglected long- } \\
\text { term programs because of } \\
\text { significant risks }\end{array}$ \\
\hline $\begin{array}{l}3^{\text {rd }} \text { generation } \\
\text { of innovation } \\
\text { process } \\
\text { (G } 3[30]) \\
\text { Early1970s - } \\
\text { mid 1980s }\end{array}$ & $\begin{array}{l}\text { Coupling model } \\
\text { Interactive }\end{array}$ & $\begin{array}{l}\text { Innovation process is a } \\
\text { combination of two pre- } \\
\text { vious models. Research, } \\
\text { developments, and mar- } \\
\text { keting operate in the sa- } \\
\text { me way. Innovation pro- } \\
\text { cess consists of large-sca- } \\
\text { le and systematic innova- } \\
\text { tion researches covering } \\
\text { many sectors and coun- } \\
\text { tries }\end{array}$ & $\begin{array}{l}\text { Linear model with feedback } \\
\text { cycles oflogically sequential, } \\
\text { functionally separated but in- } \\
\text { teracting and interdepen- } \\
\text { dent stages. Innovation pro- } \\
\text { cess combines external re- } \\
\text { sources and activities of vari- } \\
\text { ous internal departments, } \\
\text { which leads to a significant } \\
\text { time saving }\end{array}$ & $\begin{array}{l}\text { These models do not have } \\
\text { parts for further develop- } \\
\text { ment and implementation } \\
\text { of innovation. Innovation } \\
\text { process is not necessarily } \\
\text { uninterrupted }\end{array}$ \\
\hline $\begin{array}{l}\text { Transition } \\
\text { model } 1986\end{array}$ & $\begin{array}{l}\text { Kline-Rosenberg } \\
\text { chain-link model }\end{array}$ & $\begin{array}{l}\text { Interaction of internal } \\
\text { innovation model with } \\
\text { external R\&D system at } \\
\text { all stages of process }\end{array}$ & $\begin{array}{l}\text { Nonlinear model with paral- } \\
\text { lel processes in which the } \\
\text { companies (corporates) op- } \\
\text { erate through numerous re- } \\
\text { verse cycles (feedbacks) }\end{array}$ & $\begin{array}{l}\text { Neglect of cooperation } \\
\text { with external R\&D insti- } \\
\text { tutions }\end{array}$ \\
\hline $\begin{array}{l}4^{\text {th }} \text { generation of } \\
\text { innovation pro- } \\
\text { cess (G4 [30]), } \\
\text { Late1980s - } \\
\text { early 1990s }\end{array}$ & $\begin{array}{l}\text { integrated mod- } \\
\text { elthat has secured } \\
\text { success to Japa- } \\
\text { nese corporation- } \\
\text { sin developing in- } \\
\text { novation strategies } \\
\text { and entering the } \\
\text { market }\end{array}$ & $\begin{array}{l}\text { Integration of R\&D and } \\
\text { design works into produ- } \\
\text { ction. Creation of joint } \\
\text { ventures, strategic allian- } \\
\text { ces, groups uniting tech- } \\
\text { nology engineers, desig- } \\
\text { ners, marketing experts, } \\
\text { and economists }\end{array}$ & $\begin{array}{l}\text { Nonlinear model with paral- } \\
\text { lel processes. Knowledge is } \\
\text { integrated into all stages of } \\
\text { innovation process. New fo- } \\
\text { cus on production strategy, } \\
\text { development of strategy for } \\
\text { reducing R\&D time }\end{array}$ & $\begin{array}{l}\text { The model terminates in- } \\
\text { novation process before } \\
\text { its implementation; how- } \\
\text { ever, entry to market, ac- } \\
\text { ceptance, and further im- } \\
\text { provement must be incor- } \\
\text { porated into innovation } \\
\text { process }\end{array}$ \\
\hline $\begin{array}{l}5^{\text {th }} \text { generation of } \\
\text { innovation pro- } \\
\text { cess }(\text { G5 [30]) } \\
\text { Mid 1990s - } \\
\text { late1990s }\end{array}$ & $\begin{array}{l}\text { Networking pro- } \\
\text { cess integrated } \\
\text { business process } \\
\text { System Integra- } \\
\text { tion and Network- } \\
\text { ing Model (SIN } \\
\text { model). [30] }\end{array}$ & $\begin{array}{l}\text { The } 4^{\text {th }} \text { generation mod- } \\
\text { els are added with a stra- } \\
\text { tegic component of integ- } \\
\text { ration of cooperating cor- } \\
\text { porations, growing impo- } \\
\text { rtance of IT and use of } \\
\text { expert system and net- } \\
\text { works. The firms improve } \\
\text { integrated production stra- } \\
\text { tegies, strive after higher } \\
\text { flexibility }\end{array}$ & $\begin{array}{l}\text { The } 5^{\text {th }} \text { generation models } \\
\text { are micro-level models, they } \\
\text { focus attention towards pro- } \\
\text { perties of innovation process } \\
\text { network and parallelism in } \\
\text { dynamics of innovation pro- } \\
\text { cesses. However, R\&D use } \\
\text { state-of-the-art information } \\
\text { system and technologies, which } \\
\text { help to establish strategic re- } \\
\text { lations with cooperating cor- } \\
\text { porations }\end{array}$ & $\begin{array}{l}\text { The } 5^{\text {th }} \text { generation models } \\
\text { are mainly closed innova- } \\
\text { tion networks, where new } \\
\text { processes of business de- } \\
\text { velopment and marketing } \\
\text { of new products take pla- } \\
\text { ce inside corporation }\end{array}$ \\
\hline
\end{tabular}


End of Table 2

\begin{tabular}{|c|c|c|c|c|}
\hline $\begin{array}{c}\text { Innovation process } \\
\text { generation, years }\end{array}$ & Existing models & Innovation process stage & Process interrelations & Model disadvantages \\
\hline $\begin{array}{l}6^{\text {th }} \text { generation of } \\
\text { innovation pro- } \\
\text { cess Early } 21^{\text {st }} \\
\text { century till now }\end{array}$ & $\begin{array}{l}\text { Open innovation } \\
\text { Chesbrough, } 2003\end{array}$ & $\begin{array}{l}\text { Corporations and custo- } \\
\text { mers with different inten- } \\
\text { sities continuously take } \\
\text { part in various stages of } \\
\text { general activities; state- } \\
\text { owned objects of R\&D } \\
\text { and external R\&D are } \\
\text { included only at certain } \\
\text { stages of innovation pro- } \\
\text { cess }\end{array}$ & $\begin{array}{l}\text { Open innovation requires } \\
\text { new logic centered towards } \\
\text { openness and cooperation. } \\
\text { Firms use ideas coming both } \\
\text { from outside and inside. This } \\
\text { model shows vertical relati- } \\
\text { ons with suppliers and cus- } \\
\text { tomers through the whole in- } \\
\text { novation process, while ho- } \\
\text { rizontal relations are realized } \\
\text { in various forms (joint ventu- } \\
\text { res, unions, consortiums, etc.) }\end{array}$ & $\begin{array}{l}\text { Strategic networks are not } \\
\text { used sufficiently }\end{array}$ \\
\hline $\begin{array}{l}7^{\text {th }} \text { generation of } \\
\text { innovation pro- } \\
\text { cess Under for- } \\
\text { mation }\end{array}$ & $\begin{array}{l}\text { Extended innova- } \\
\text { tion network }\end{array}$ & $\begin{array}{l}\text { Communities with net- } \\
\text { work web sites are open } \\
\text { and flexible means for } \\
\text { pragmatic implementati- } \\
\text { on of innovation concep- } \\
\text { tions. In new network pa- } \\
\text { radigm one can combine } \\
\text { linear and coupling pro- } \\
\text { cesses depending on de- } \\
\text { mands. However, this will } \\
\text { require new ways of co- } \\
\text { operation between cor- } \\
\text { porations and individual } \\
\text { innovators }\end{array}$ & $\begin{array}{l}\text { These models combine open } \\
\text { and network innovation } \\
\text { models for forming integrat- } \\
\text { ed innovation network in or- } \\
\text { der to fully utilize all open } \\
\text { innovation concepts; corpo- } \\
\text { rations shall develop inte- } \\
\text { grated knowledge networks } \\
\text { to supportinnovation knowl- } \\
\text { edge supply chain. Focusing } \\
\text { on innovators }\end{array}$ & Will be shaped with time \\
\hline
\end{tabular}

+ diffusion of innovation (to spread the already mastered innovation in new regions and in new financial and economic situation).

Depending on the depth of the proposed changes, the authors [2] have distinguished the following types of innovations:

- The radical innovations of technical/engineering nature usually relate to the process of introducing new products, which subsequently necessitates the use of new technologies (the technological aspect of innovation) in introducing a new way of corporate management, which may lead to changes in production technology and service delivery (the organizational aspect of innovation);
- The recombination innovations relate to the use of existing technological, organizational, and industrial solutions in order to create new types of products, technologies or control systems;

- The modification innovations are minor changes in the existing range of products, technologies, and control systems in order to improve them;

- The management innovations, depending on the level of management, can be: inter-organization$\mathrm{al}$, that is, those that arise and spread at the macro level, within the whole economy, industry; or internal, the scope of which is determined by the boundaries of separate organization or department.

From the above, one can see how the idea of innovation and innovation process changed over 
time. Today, there are many types of innovations, but so far there has been none single classification of innovations. The classification of innovations proposed below enables to summarize the majority of the types of innovations (Table 1).

The changes in innovation process since the early $19^{\text {th }}$ century have been studied; the sequence of generations and models corresponding to each generation have been proposed (Table 2).

The research has enabled to see how the innovation conception has changed with time, to systematize the existing types of innovations by different features and properties and to categorize them, as well as to consider new types of innovation. The given comparison has made it possible to see how the innovation process and its models have changed, to show the stages of its development with respective features and disadvantages.

\section{CONCLUSIONS}

The creation of unified innovation classification by various features with respective English-language terminology has enabled to combine and to put in order the majority of existing innovation types.

Innovation classification and sequence of innovation process generations, as shown in this research, can help innovators to find their strategy of innovation development depending on opportunities and conditions they have, insofar as there is no universal algorithm for individual corporations how to become innovative and how to survive in the modern market economy.

\section{REFERENCES}

1. The Law of Ukraine «On Innovation Activities» № 40-IV dated 04.07.2002.

2. Mikhailova, L., Gutorov, O., Turchina, S., Sharko, I. (2015). Innovation Management. Kyiv [in Ukrainian].

3. Fedorova, V., Tatarchuk, Yu. (2015). Theoretical Information on Innovation. Economic space, 100, 66-73 [in Ukrainian].URL: http://nbuv.gov.ua/UJRN/ecpros_2015_100_9 (Last accessed: 12.03.2018).

4. Tard, G. (1903). The lawes of imitation. New York: Henry Holt and Company.URL: https://www.google.com/url?sa=t $\& \mathrm{rct}=\mathrm{j} \& \mathrm{q}=\& \mathrm{esr}=\mathrm{s} \&$ source= $=$ web $\& \mathrm{~cd}=2 \& \mathrm{cad}=\mathrm{rja} \& u a c t=8 \&$ ved $=0$ ahUKEwizvN2TjILaAhWIiCwKHdQXAIcQFggvMA E\&url=https\%3A\%2F\%2Fmonoskop.org\%2Fimages\%2F3\%2F35\%2FTarde_Gabriel_The_Laws_of_Imitation.pdf\&usg=A OvVaw126PlzoXKbxUM7qLyVEehi (Last accessed: 12.03.2018).

5. Schumpeter, J.A. (1934). The Theory of Economic Development: An Inquiry into Profits, Capital, Credit, Interest, and the Business Cycle. Cambridge: Harvard University Press. URL: https://pdfrog.com/download/the_theory_of_economic_ development_an_inquiry_into_profits_capital_credit_interest_and_the_business_cycle_joseph_a_schumpeter.pdf (Last accessed: 12.03 .2018$)$.

6. Schumpeter, J.A. (1939). Business Cycles: A Theoretical, Historical, and Statistical Analysis of the Capitalist Process. New York: McGraw-Hill.URL: https://www.researchgate.net/publication/319503069_Schumpeter_Joseph_Alois_1939 Business_Cycles_A_Theoretical_Historical_and_Statistical_Analysis_of the_Capitalist_Process (Last accessed: 12.03.2018).

7. Kotsemir, M., Meissner, D., Abroskin, Al. (2013). Innovation Concepts and Typology - An Evolutionary Discussion. Higher School of Economics Research Paper. WP BRP 05/STI/2013. URL: https://wp.hse.ru/data/2013/04/30/1296740 743/05STI2013_new.pdf (Last accessed: 12.03.2018).

8. Smith, G.E., Malinowski, B., Spinden, H.J., Goldenweiser, A. (1927).Culture: The Diffusion Controversy. New York: Norton and Co.URL: https://archive.org/details/culturediffusion00smitrich (Last accessed: 12.03.2018).

9. Godin, B. (2017). Models of Innovation: The History of an Idea. Cambridge, MA: MIT Press. URL: https://www. kobo.com/us/en/ebook/models-of-innovation (Last accessed: 12.03.2018).

10. Maclaurin, W.R. (1953). The Sequence from Invention to Innovation and its Relation to Economic Growth. Quarterly Journal of Economics, 67(1), 97-111.

11. Mansfield, E. (1971). Research and Innovation in the Modern Corporation. New York: Norton and Co.URL:https:// books.google.com.ua/books?id=GdewCwAAQBAJ\&pg=PA32\&lpg=PA32\&dq=Mansfield,+E.+Research+and+Innovation + in + the + Modern + Corporation. \&source $=$ bl\&ots $=$ wraPL_TsmH\&sig=T7G_oTcVN53_66cEuPV834neGRs\&hl=ru\&sa $=$ X \&ved=0ahUKEwifle7fmILaAhVJKywKHbJhAccQ6AEIXDAJ\#v=onepage\&q=Mansfield\%2C\%20E.\%20Research\%20 and\%20Innovation\%20in\%20the\%20Modern\%20Corporation.\&f=false (Last accessed: 12.03.2018). 
12. Godin, B. (2008). Innovation: The History of a Category. Project on the Intellectual History of Innovation. Working Paper № 1 URL: http://www.csiic.ca/PDF/IntellectualNo1.pdf(Last accessed: 12.03.2018).

13. Tidd, J., Bessant, J.(2013). Managing Innovation:Integrating Technological, Marketand Organizational Change( $5^{\text {th }}$ ed.). London: John Wiley \& Sons Ltd.URL: http://bookfreenow.com/download/tidd-bessant-managing-innovation-5-edition/ (Last accessed: 12.03.2018).

14. Pyatnitskaya, G.T. (2013). Innovative development of organizations: integral components and factors of influence. Marketing and innovation management, 3, 76-91 [in Ukrainian].

15. Mensh, G. (1979). Stalemate in Technology: Innovation Overcome the Depression. Cambridge, Mass: Ballinger Pub. Co. URL: https://books.google.com.ua/books/about/Stalemate_in_technology.html?id=DW2aAAAAIAAJ\&redir_esc=y (Last accessed: 12.03.2018).

16. Tidd, J., Bessant, J., Pavitt, K. (2005). Managing innovation: Integrating technological, market and organizational change ( ${ }^{\text {rd }}$ ed.). London: John Wiley \& Sons Ltd.URL: https://erl.ucc.edu.gh/jspui/bitstream/123456789/3001/1/\%5BJo e_Tidd\%2C_John_Bessant\%2C_Keith_Pavitt\%5D_Managing_In\%28BookZZ.org\%29.pdf (Last accessed: 12.03.2018).

17. Clayton, M., Derek van Bever. (2014). The Capitalist's Dilemma.Harvard Business Review, 92(6), 60-68.URL: https://hbr.org/2014/06/the-capitalists-dilemma (Last accessed: 12.03.2018).

18. Chesbrough, H. (2011).Open Services Innovation: Rethinking Your Business to Grow and Compete in a New Era (1 $1^{\text {st }}$ ed.). San Francisco, CA : Jossey-Bass.URL:https://epdf.tips/queue/open-services-innovation-rethinking-your-business-togrow-and-compete-in-a-new-e.html (Last accessed: 12.03.2018).

19. The immensity of innovation: an interview with Henry Chesbrough [in Ukrainian].

URL:http://www.management.com.ua/interview/int316.html.(Last accessed: 12.03.2018).

20. Chesbrough, H. (2003). Open Innovation. The New Imperative for Creating and Profiting from Technology.Harvard Business Press. URL: https://eclass.uoa.gr/modules/document/file.php/ECON197/Papers\%20Strategy/Chesbrough\%20 2003\%20The\%20Era\%20of\%20Open\%20Innovation.pdf (Last accessed: 12.03.2018).

21. Rud, N.T. (2013). Open innovation - a new paradigm of innovation development. Ser: Economy, 21, 81-85 [in Ukrainian].

22. Christensen, C.M. (2004). The innovator's dilemma. When Ner Technologies Cause Great Firms to Fail. Moscow: Alpina Business Books [in Russian].

23. Christensen, C. M., Raynor M.E. (2004).The Innovator's Solution: Creating and Sustaining Successful Growth. Moscow: Alpina Business Books[in Russian].

24. Christensen, C.M., Roth, E.A., Scott, D.A. (2008). Seeing What's Next: Using Theories of Innovation to Predict Industry Change.Moscow: Alpina Business Books[in Russian].

25. Kim, W. Ch., Mauborgne, R. (2017). Blue ocean Strategy: How to Create Uncontested Market Space and Make the Competition Irrelevant. Kharkiv: Book Club «Family Leisure Club» [in Ukrainian].

26. Tiwari, R., Herstatt, C. (2012). India - A Lead Market for Frugal Innovations? Extending the Lead Market Theory to Emerging Economies. Working Paper № 67, Institute of Technology and Innovation Management, Hamburg University of Technology, Germany.URL: https://papers.ssrn.com/sol3/papers.cfm?abstract_id=1998411 (Last accessed: 12.03.2018).

27. Tucker, R.B. (2006). DrivingGrowthThroughInnovation: How Leading Firms are Transforming Their Futures. Moscow: Olympus business [in Russian].

28. Keeley, L., Pikkel, R., Quinn, B., Walters, H. (2013).Ten Types of Innovation. The Discipline of Building Breakthroughs. Hoboken, New York: John Wiley \& Sons.URL: http://cimp.nd.edu/assets/155986/020315_ten_types_innovation.pdf(Last accessed: 12.03.2018).

29. Muriithi, S. (2015). 18 types of innovation: Which one matches your small businessidea?URL: https://thewordgarage.wordpress.com/2015/06/18/18-types-of-innovation-which-one-matches-your-small-business-idea/(Last accessed: 12.03.2018).

30. Rothwell, R. (1994). Towards the fifth-generation innovation process. MCB UP Ltd. International Marketing Review, 11(1), 7-31. URL: https://www.emeraldinsight.com/doi/abs/10.1108/02651339410057491 (Last accessed: 12.03.2018).

31. Tebekin, A.V. (2014). Innovative management: a textbook for bachelors. Moscow: Publisher Yurayt[in Russian].

32. Taferner, B. (2017). A next generation of innovation Models? An integration of the Innovation process model big Picture towards the different Generations of models ReviewofInnovationand Competitiveness.AJournalofEconomicandSocial Research, 3(3), 47-60.URL: https:/ $/$ www.google.com/url? sa =t \&rct=j\&q=\&esrc=s\&source=web\&cd=1\&cad=rja\&uact=8\& ved=0ahUKEwjGpuWSo4LaAhXBkiwKHYyZBuIQFggqMAA\&url=https\%3A\%2F\%2Fhrcak.srce.hr\%2Ffile\%2F276039 \&usg=AOvVaw0umgg4GPYcOkAjCIsIe8bp (Last accessed: 12.03.2018).

33. Marinova, R., Phillimore, J. (2003). Models of innovation. The International Handbook on Innovation. Oxford: Elsevier. URL: https://www.sciencedirect.com/science/article/pii/B978008044198650005X (Last accessed: 12.03.2018). 
34. Kotsemir, M., Meissner, D. (2013). Conceptualizing the Innovation Process Trends and Outlook. Series: science, technology and innovation WP BRP 10/STI/2013. URL: https://mpra.ub.uni-muenchen.de/46504/1/MPRA_paper_46504. pdf (Last accessed: 12.03.2018).

35. Preez, ND. Du., Louw, L., Essmann, H. (2014). An Innovation Process Model for Improving Innovation Capability. Journal of High Technology Management Research, 26, 1-24. URL: https://pdfs.semanticscholar.org/d85a/97a149efad7d65 ea1c7bdc4d7a6e2b8fdc19.pdf (Last accessed: 12.03.2018).

Received 23.02.18

\author{
Ю.А. Даниленко \\ Інститут сцинтиляційних матеріалів НАН України, \\ пр. Науки, 60, Харків, 61072, Україна, \\ +380 57341 0292, j.danilenko@isma.kharkov.ua

\section{ХАРАКТЕРИСТИКИ ТА КЛАСИФІКАЦІЇ ІННОВАЦІЙ ТА ІННОВАЦЙНОГО ПРОЦЕСУ}

Вступ. Протягом останніх років інновації стали синонімом розвитку швидкого технологічного прогресу. Використання інноваційних технологій та сучасних моделей інноваційного процесу дає можливість підприємствам бути на крок попереду за своїх конкурентів.

Проблематика. Пошук нових напрямків для появи інновацій вимагає вивчення історіографії інновацій та відстеження послідовності етапів розвитку інноваційних процесів. Таке дослідження дає можливість появи на підприємствах сучасних інноваційних моделей, що дозволяють створювати умови для розвитку навичок, необхідних для впровадження інновацій у будь-якому контексті.

Мета. Дослідити існуючі класифікації інновацій та моделей інноваційного процесу, систематизувати та розробити власні класифікації стосовно досліджуваних об'єктів.

Матеріали й методи. У процесі дослідження використано методи логіки та порівняльного аналізу, методи системного підходу та аналогій. Матеріалами для дослідження слугували публікації зарубіжних та українських вчених, які вивчали зазначену проблематику.

Результати. Проведено дослідження історіографії щодо термінів «інновація» та «інноваційний процес». Особливу увагу приділено розгляду «відкритих інновацій». Це дозволило відстежити як змінювалось поняття «інновації» з часом, класифікувати існуючі типи інновацій за різними ознаками та відокремити їх відповідно до кожної категорії. Також розглянуто як змінювався інноваційний процес та його моделі, показано етапи його розвитку з відповідними ознаками та недоліками.

Висновки. На сьогодні існує значна кількість типів інновацій, з'являється значна кількість нових, але до цього часу немає єдиної їх класифікації. Розглянуті класифікації вітчизняних і зарубіжних вчених помітно відрізняються між собою за різними ознаками. Також немає єдиного алгоритму для окремо взятого підприємства не тільки як стати інноваційним, але і як саме вижити в умовах сучасної ринкової економіки. Свій інноваційний шлях керівництво підприємства самостійно обирає відповідно до можливостей та умов, в яких воно перебуває.

Ключ о в і слов в: інновація, інноваційний процес, класифікація, історіографія, етап, розвиток, характеристика.

\author{
Ю.А. Даниленко \\ Институт сцинтилляционных материалов НАН Украины, \\ пр. Науки, 60, Харьков, 61072, Украина, \\ +380 57341 0292, j.danilenko@isma.kharkov.ua

\section{ХАРАКТЕРИСТИКИ И КЛАССИФИКАЦИИ ИННОВАЦИЙ И ИННОВАЦИОННОГО ПРОЦЕССА}

Введение. В течение последних лет инновации стали синонимом развития быстрого технологического прогресса. Использование инновационных технологий и современных моделей инновационного процесса дает возможность предприятиям быть на шаг впереди своих конкурентов.

Проблематика. Поиск новых направлений для появления инноваций требует изучения историографии инноваций и отслеживания последовательности этапов развития инновационных процессов. Это дает возможность для по- 
явления на предприятиях современных инновационных моделей, которые позволяют создавать условия для развития навыков, необходимых для внедрения инноваций в любом контексте.

Цель. Исследовать существующие классификации инноваций и моделей инновационного процесса, систематизировать и разработать собственные классификации относительно исследуемых объектов.

Материалы и методы. В процессе исследования использовались методы логики и сравнительного анализа, методы системного подхода и аналогий. Материалами исследования были публикации зарубежных и украинских ученых, исследовавших эту проблематику.

Результаты. Проведено исследование историографии по понятиям «инновация» и «инновационный процесс». Особое внимание уделено рассмотрению «открытых инноваций». Это позволило отследить, как менялось понятие «инновации» со временем, классифицировать существующие типы инноваций по различным признакам и отделить их по каждой категории. Также рассмотрено, как менялся инновационный процесс и его модели, показано этапы его развития с соответствующими признаками и недостатками.

Выводы. На сегодня существует значительное количество типов инноваций, появляется много новых, но до сих пор нет единой их классификации. Рассмотреные классификации отечественных и зарубежных ученых заметно отличаются по различным признакам. Также нет единого алгоритма для отдельно взятого предприятия не только как стать инновационным, но и как выжить в условиях современной рыночной экономики. Свой инновационный путь руководство предприятия самостоятельно выбирает в соответствии с возможностями и условиями, в которых оно находится.

Ключевые слова: инновация, инновационный процесс, классификация, историография, этап, развитие, характеристика. 